\title{
Cannes 2001 Report
}

\author{
By Ron Holloway
}

Fall 2001 Issue of KINEMA

CANNES INTERNATIONAL FILM FESTIVAL 2001

Two events devotee of made the $54^{\text {th }}$ Festival International du Film (9-20 May 2001) particularly memorable. The first was the news that, after 22 years as délégué général, Gilles Jacob stepped up to become Président while handing down the reins to Thierry Frémaux, the latter now divides his time between Cannes and duties as head of the Institute Lumière in Lyons. The other was the presence on the Croisette of seven previous Palme d'Or directors: Francis Ford Coppola (The Conversation, 1974, and Apocalypse Now, 1979), Ermanno Olmi (The Tree of Wooden Clogs, 1978), Shohei Imamura (The Ballad of Narayama, 1983, and The Eel, 1997), David Lynch (Wild at Heart, 1990), Joel and Ethan Coen (Barton Fink, 1991), and Abbas Kiarostami (The Taste of Cherries, 1997). One might add, too, that over the past quarter century each of their eight award-winning films helped considerably to set the tone and style of the world's most revered film festival.

\section{Apocalypse Now Redux}

In the case of Apocalypse Now -- aka Apocalypse Now Redux, to denote a new version of an old film -- Francis Ford Coppola returned to Cannes with the completed version of his work-in-progress presented here 22 years ago. No less than 53 minutes were added to the re-edited 203-minute version, in addition to a re-mastered Technicolor transfer and a re-mastered soundtrack. Further, Coppola was able to enlist the aid of two former collaborators, cameraman Vittorio Storaro and editor Walter Murch, to assist him on the director's cut of a classic that now ranks with Orson Welles's Citizen Kane as one of the world's legendary film productions. When the film is "re-released," cineastes will relish the added French plantation sequence, the inserted rescue of stranded Playmates by a patrol boat crew "for favours received," and the scraping of the animal sacrifice scene in the original (one of several endings Coppola could choose from).

Cannes natives and visitors were treated to another first in festival history: a gratis open-air screening of Apocalypse Now Redux on the harbor-front next to the Palais des Festivals, viewed by hundreds under balmy weather conditions. The occasion was made possible when the set for Baz Luhrmann's Moulin Rouge (Australia) came down shortly after its opening night presentation. Further, since Coppola's film had already run out-of-competition on a sold-out Friday evening, the additional outdoor screening gave the general public a welcomed chance to view a festival classic. "We plan to offer more free public screenings in the future," confirmed Thierry Frémaux in an interview with this reporter.

\section{Palme d'Or: Nanni Moretti's The Son's Room}

This was not the first time that the International Jury and the International Critics (FIPRESCI) Jury agreed on the same film for top honours at Cannes. Nonetheless, when the presidents of both juries -- Liv Ullmann for the International Jury, Derek Malcolm for the FIPRESCI Jury -- admitted to the same split decision, each favouring Nanni Moretti's La stanza del figlio (The Son's Room, Italy) over Michael Haneke's La pianiste (The Piano Teacher, Austria-France) for the Palme d'Or and the FIPRESCI Award, this did make news and triggered some discussion on whether the best film won. Further, Haneke's The Piano Teacher received not only the runner-up Grand Prix, but Isabelle Huppert in the title role was also awarded Best Actress (the only unanimous decision of the jury) together with Benoît Magimel as Best Actor. And Derek Malcolm, president of the FIPRESCI Jury, confirmed that only one vote separated The Son's Room from The Piano Teacher.

Nanni Moretti is no stranger to the Cannes competition. Nearly a quarter-century ago, his tragicomedy Ecce Bombo (1978) introduced the writer-director-actor in the persona of a 24-year-old student revolutionary trying to separate his political beliefs from his private phobias -- and the Italian auteur has been doing it ever since in a string of semi-autobiographical cult films under his Sacher Film trademark (named for his favourite Viennese chocolate cake). Caro diario (1993), awarded Best Director at the 1994 Cannes festival, is a free-wheeling, first-person-narrative account of his phobias that ends on a personal note: in the "On My Vespa" episode we follow Moretti in a seemingly endless camera-take as he cruises the streets of Rome 
-- until he reaches the spot where Pasolini was murdered. In Aprile (1998), the sequel to Dear Diary, he's a would-be documentarist who can't separate his private life (he's the father of a new-born son) from a political commitment to speak out against the wave of rightist support for Silvio Berlusconi. The documentary is finally shelved for lack of anything relevant and up-to-date to say.

Often cited as a "low-key Woody Allen," nowhere is this tag more appropriate than in The Son's Room. Nanni Moretti plays a psychoanalyst in the small town of Ancona on the Adriatic coast, a provincial nest where the family is the centre of the world and where a death in the family tests the power of love. "My wish was to show how sadness often divides people who love one another," said Moretti in an interview. Following the unexpected death of his teenaged son on a diving excursion with friends, Giovanni (Moretti) is unable to help his patients unlock their emotional psychoses, much less resolve his own feelings of remorse and blame for failing to spend that tragic Sunday with his son instead of responding to an emergency call. The same bitter feeling of loss and emptiness is felt by his wife Paola (Laura Morante, a standout also in Bianca, 1984, arguably Moretti's best film), who can no longer keep her mind on publishing art books, and their teenaged daughter, who unleashes her anger on the school basketball court. The spiral of life is about to spin completely out of control when a warm love letter for the son arrives from a girl he once met briefly during a camping outing. Interest in the girl is awakened, the mother makes a phone call, and one day the girl joins the shattered family circle to tell her story.

True, Nanni Moretti walks a thin line between solace and sentiment in The Son's Room, but he does so with a sure hand for those profound moments of painful family separation. When the sister asks that the lid of the coffin be lifted again so that she can see, and touch, her brother for the last time, the simplicity of the scene cuts to the bone and confirms Moretti as a director with an intuitive sense for family tragedy. Let it be said, too, that if you strip away the film's superficial components, you are confronted with a poignant, sometimes heart-rending, modern-dress variation on the passion play. Add to this the news that Moretti himself recently recovered from a lingering illness, plus the fact that The Son's Room has been a commercial hit since its release in Italy last March, and you have a Palm winner well on its way to becoming a box office winner the world over too.

\section{Grand Prix: Michael Haneke's The Piano Teacher}

Michael Haneke's La pianiste (The Piano Teacher), is adapted from a novel by Austrian writer-dramatist Elfriede Jelinek. Asked why he had picked up an antiquated screenplay written a decade ago, then updated it with further changes to fit his stylistic vision, Haneke replied: "Firstly, because someone suggested it. Secondly, because of the story's extremely complex observations about society that go beyond private interrelationship. And, thirdly, because there are three great roles." A fourth reason could also be added: the presence of Isabelle Huppert in the title role. "In my opinion she's the best actress I know in Europe, if not the entire world. On the one hand, she has the sensitivity and ability to show suffering. On the other, she can show the character's cold-bloodedness and looks good at the same time."

Haneke is best remembered at Cannes for driving hypersenitive viewers from their seats when his psychodrama Funny Games (1997) was presented in 1997 the competition. A weird tale about a pair of murderous psychopaths toying with their victims before killing them, it was followed a year later with the more accessible Code inconnu (Code Unknown). On the surface a chronicle about the socially alienated and the psychologically disturbed peopling the streets and metros of Paris, Code Unknown offers a harsh portrait of urban ethics found in most European capitals. He wanted the audience to feel the coldness of the consumer society, the incapacity of social classes to intercommunicate, the fears emanating from xenophobia and prejudice, the Babylonian confusion of languages, and the media's clichés about the "have's" and the "have not's."

Discovered for Cannes by Pierre-Henri Deleau, Michael Haneke formulated his theories on the modern phenomenon of "glaciation" in a trilogy of psychological studies presented in the Directors Fortnight. In these films he focused on people who had lost both the ability, even the desire, to communicate. Furthermore, he feels that these emotionally disturbed individuals are representative of a morally ruptured society. In The Seventh Continent (1989) deranged parents lock themselves into their apartment, poison their daughter, and then commit a double suicide. In Benny's Video (1992), self-centered middle-class parents attempt to cover up a senseless murder committed by their lonely teenaged son, who is living a stunted childhood with 
his camcorder and has completely lost touch with reality. In 71 Fragments of a Chronology of Chance (1994) an emotionally disturbed university student opens fire with a gun in a bank and randomly killed a number of people he doesn't even know.

In The Piano Teacher Erika Kohut (Isabelle Huppert), a middle-aged teacher at the Vienna Conservatory, is living an hermetic, love-hate existence with a tyrannical mother (Annie Girardot) in which there is no room for men, heightened by the commitment of her father to an insane asylum. Worse, her sex life has been reduced to voyeurism and masochistic diversions -- that is, until Walter Klemmer (Benoit Magimel), one of her young pupils into ice-hockey as well as music, decides to seduce her. Attracted yet repelled by his advances, Erika sinks deeper into her self-imposed malaise of selfish spite and shameless mortification until she loses completely control of herself.

"Victims interest me more than perpetrators," says Michael Haneke. "Women are more interesting because they're further down the line in the pecking order. Men bore me." As for why he adapted a novel by Jelinek, whose style of writing is pegged to linguistic subtleties, he admitted to a desire to return to Vienna because he enjoys the psychological give-and-take in the German language. Thus, key supporting roles are played by prominent German stage-and-screen actors (Udo Samel, Susanne Lothar, the latter seen in Funny Games). All the same, The Piano Teacher is a festival anomaly: a Viennese story shot in French with the German roles dubbed. Is this the version that will be released in Austria?

\section{The Balkans: Danis Tanovic's No Man's Land}

Awarded Best Screenplay, Danis Tanovic's No Man's Land is a tale about the insanity of the war in exYugoslavia. When the Bosnian Ciki (Branko Djuric) and the Serb Nino (Rene Bitorajac), two enemy soldiers, get stranded between the lines in the summer of 1993 and find they have little reason to continue the conflict on personal grounds, they have to find a way out of their grotesque quandary. Along comes a friendly UN soldier (Georges Siatidis), who likewise gets pulled into the mess despite orders not to get involved. Before long, the incident explodes into an international news event -- Balkan-style, comic and bitter at the same time. After all the diplomatic cards are played, the outcome is still a disaster: the dead transported from the scene in a helicopter, one Bosnian soldier left behind, lying atop a mine that cannot be defused -- like a crucified Christ.

One might argue that No Man's Land, a Belgian-French-Italian-British-Slovenian coproduction, is coming a decade too late. However, the Bosnian writer-director has paid his dues in this respect. Danis Tanovic belongs to the same SAGA (Sarajevo Group of Authors) collective, whose wartime documentation during the siege of Sarajevo was cited and praised at several international film festivals. And Cannes veterans well remember a hard-hitting omnibus film programmed by Pierre-Henri Deleau at the 1994 Directors' Fortnight: $M G M$-- Man, God, Monster, in which each of the three episodes by four filmmakers focused on events from a perspective inside the sieged city. The picture was dark, depressing, debilitating.

Another year passed, the war ended, and some enterprising pseudo-aficionados sensed their opportunity. Spanish director Gerardo Herrero's Territorio Comanche, a competition entry at the 1997 Berlinale, was more of a laugh parade about "dangers to journalists" than about the siege itself. British director Michael Winterbottom's Welcome to Sarajevo, a competition entry at the 1997 Cannes festival, came across as a speculative rehash of well-known TV documentation that sugar-coated the plight of the suffering.

Far better, so far as taking the pulse of a besieged city was concerned, was Bosnian director Ademir Kenovic's The Perfect Circle, the opening night presentation at the 1997 Directors' Fortnight. Penned by poet-dramatist-screenwriter Abdullah Sidran (he scripted for a young Emir Kusturica Do You Remember Dolly Bell?, awarded the Opera Prima Prize at Venice in 1981, followed by Father's Away on a Business Trip, awarded the Golden Palm at Cannes in 1985), The Perfect Circle interpreted the meandering thoughts and stubborn determination of a resolute alcoholic to stay put despite all -- and to offer needed shelter to two orphaned boys from a nearby village.

When I visited the 2nd Sarajevo festival in the fall of 1996, the siege had just ended and The Perfect Circle was in postproduction. Also, the FIPRESCI (International Critics) Prize at the Felix European Film Awards had been given to the SAGA Group under the aegis of Ademir Kenovic. The recognition contrasted with a crass case of current government corruption. By hook or by crook, a veteran septuagenarian director 
from Zagreb had obtained a funding grant of $\$ 1$ million from certain key parliamentary members in the Bosnia-Herzegovina federation to make a film titled Sarajevo that would feature international stars in the cast. The film was never made and the money disappeared, while the SAGA Group had to scrape together modest funding for a "black book" titled Sarajevo in War, 1992-1995, Filmography, published in 1998.

Listed in this vital Sarajevo in War filmography are several shorts, documentaries, and videos made with the help of writer-director Danis Tanovic, who was responsible for the Bosnian army's film archive. He himself filmed over 300 hours of footage shot on the front lines, material that was used in news reports broadcast around the world. Together with Dino Mustafic, Tanovic wrote and directed My Mother the Sehit (1992), a poignant 12-minute short produced for SAGA by Ademir Kenovic and Ismet Arnautalic. The story of a boy whose mother was killed in the early stages of the war, he brings a rose from her garden to place on her grave -- only to find that it has mysteriously disappeared upon his return. In the equally impressive Portrait of the Artist in the War (1994), a 19-minute documentary, Tanovic explores how indifference gradually gives way to commitment in an artist's approach to the ongoing war.

The siege over, Danis Tanovic transferred his filmmaking base to Belgium while still maintaining ties and allegiance to Bosnia. His documentary L'Aube (Dawn) (1997), awarded several prizes at international festivals, depicts the anxiety of a blind man who waits as a helpless refugee for his family to join him. And his documentary Ça ira (1999), about life and times in present-day Bosnia, also received multiple festival awards. Now comes No Man's Land, a debut feature film set in 1993 at the height of the Bosnian war, and here again one wonders how this debut feature film could get made at all. As the story goes, Tanovic had the good fortune to attend the São Paulo festival, where he posed the idea of a tragicomedy about his war experiences to festival guests.

"We found the money in six months," said Tanovic at his Cannes press conference. "Thanks to the screenplay, which was liked a lot." Asked whether No Man's Land was based on personal experiences, he responded: "Of course, my war experience is very present, but this is a story, a fiction film, a film that I thought up. It's about my thoughts and my view on everything that happened to us."

To say more might lessen the reader's own viewing experience of the film. When Danis Tanovic, together with his actors and his production team, took the stage following the premiere presentation of No Man's Land in the Grand Théâtre Lumière at Cannes, they were greeted with a standing ovation that lasted ten minutes. Sales for the "Cannes discovery" -- cited in the press as a low-budget Belgian French-British-ItalianSlovenian coproduction -- followed swiftly.

This said, you can well imagine the kind of greeting Danis Tanovic will receive when No Man's Land opens the Seventh Sarajevo Film Festival on August 17th in the 2,500-seat Open Air Cinema at the Obala Art Centre.

\section{David Lynch and the Coen Bros}

David Lynch and Joel Coen shared Best Director Award for a pair of films anchored in Hollywood traditions yet far enough away from current formulas to challenge even the most astute critic and historian as to depth and meaning. Lynch has called Mulholland Drive (referring to a curving highway running along the edge of Hollywood Hills) "a love story in the city of dreams" -- and takes it as a compliment when the film is compared with Nathaniel West's The Day of the Locust (published in 1939, when he was working as a scriptwriter in Hollywood, and filmed by John Schlesinger in 1975). In fact, the opening scene of the car accident on Mulholland Drive hints of West's own death at 36 in a car crash in 1940, just as the writer was about to gain fame for his black comedies and satirical indictment of the American Way of Life.

Originally, Mulholland Drive was conceived as a sequel to Lynch's successful Twin Peaks TV series (1992) -- later made into Fire Walk with Me, the movie version presented at the 1994 Cannes festival -- but when the pilot was rejected by $\mathrm{ABC}$, it proved to be a rich find for a scary, bizarre, sensuous exploration of the imaginary world of dreams and nightmares in the Hollywood tinsel factory. After the crash on Mulholland Drive, Rita (Laura Elena Harring), an amnesiac brunette, is taken in by Betty (Naomi Watts), a goodhearted blonde new to Hollywood who's set on resolving the amnesia dilemma. Later, Rita morphoses into Camilla and Betty into Diane, their roles changing and interchanging much as dreams give way to nightmares without any rational reason. Try to make sense out of Mulholland Drive, and you get lost in the labyrinth 
midway through the film. Lean back in your seat to relax, and you will be treated to some finely rendered acting scenes by the pair, supported by former Hollywood dancer Anne Miller as Coco Lenoix in a sparkling cameo.

As for Joel Coen's The Man Who Wasn't There, scripted with brother Ethan, the Hollywood reference here is to writer James M. Cain (1892-1977), one of the masters of the hard-boiled detective story whose film noir adaptations rank among the best in the Hollywood genre. Cain, a master at weaving a web of intrigue from the subjective viewpoint of the murderer or the victim, provided the plots for three film noir classics of the 1940s: Billy Wilder's Double Indemnity (written 1934, filmed 1944), Tay Garnett's The Postman Always Rings Twice (written 1936, filmed 1946), and Michael Curtiz's Mildred Pierce (written 1941, filmed 1945). Contrary to intricate detective stories by Dashiell Hammett and Raymond Chandler, James M. Cain preferred a tight narrative that linked the crime unmistakably to a romantic triangle with sexual obsession as the key motivation. Thus, it was no wonder that European directors got their hands on his first novel long before Hollywood did: Pierre Chenal adapted The Postman Always Rings Twice to the screen first as Le Denier Tournant (The Last Shift) (France, 1939), followed by Luchino Visconti's neorealist Ossessione (Italy, 1942).

The Cain giveaway in the Coens' The Man Who Wasn't There is not the black-and-white homage to the film noir tradition so much as the blackmail letter written by the husband to the adulterer that both confirms his suspicions and paves the way for the chain-reaction of murder and homicide. Also, the setting is a barbershop in a sleepy hamlet in northern California, a stopover akin to the roadside café in The Postman Always Rings Twice. When Ed (Billy Bob Thornton), a chain-smoking barber, bares his thoughts in the opening sequence to tell us how dull his life is, he starts the ball rolling by succumbing to the ploy of a passing conman to invest in a dry-cleaning scam. This leads to the anonymous blackmail letter, the accidental killing of the adulterer, the suicide of his wife sentenced to death for the killing, and so on until the final twist at the end of the prolonged, yet spellbinding narrative.

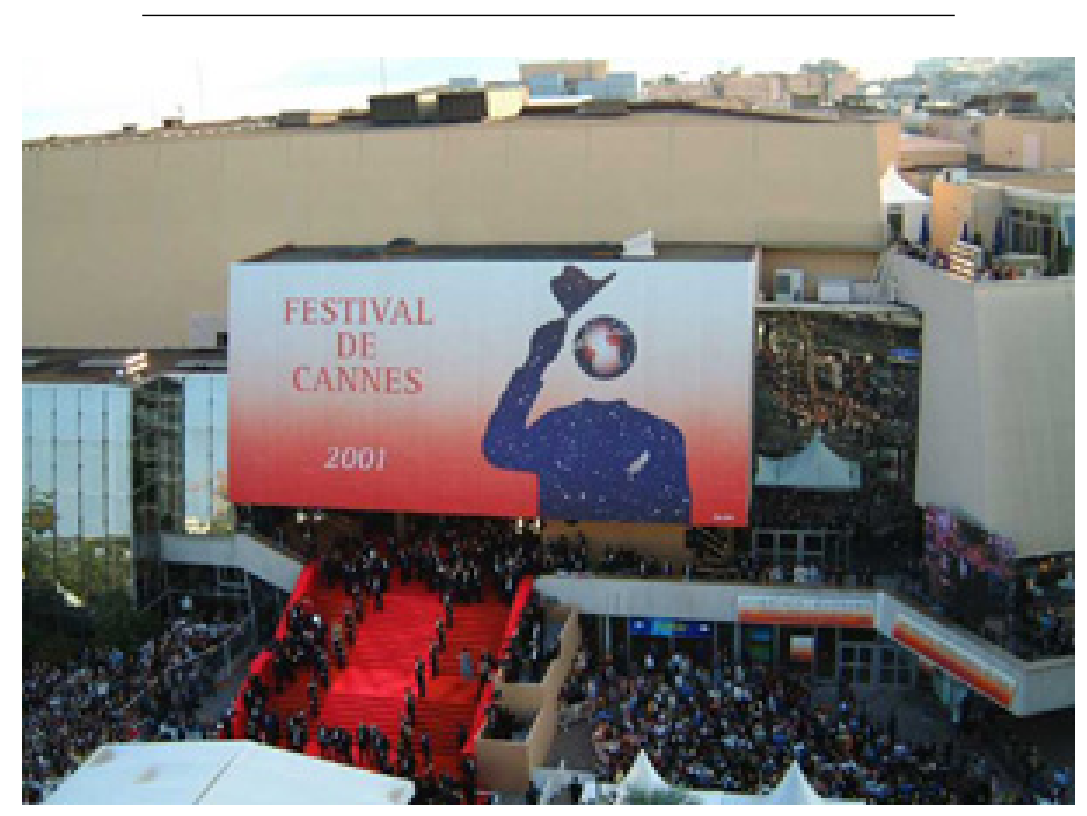

Figure 1: Cannes - Festival palace

\section{Masters I: Ermanno Olmi's The Profession of Arms}

As befits a master filmmaker -- indeed, at 69, the last of the great Italian postwar masters -- Ermanno Olmi is reluctant to give interviews. To get him to say much about why he, a humanist director, would attempt to make a film about $\mathrm{Il}$ mestiere delle armi (The Profession of Arms) is almost a waste of time. He prefers to let his films speak for themselves. 
One reason for Olmi's reticence is the embarrassment of having to answer nagging questions about the inspiration for his films and the meaning behind their odd-sounding titles. Or why nearly five years of inactivity lay between the Cannes premieres of The Tree of Wooden Clogs (1978 winner of the Palme d'Or) and Cammina Cammina (1983), then another four years until Long Live the Lady (1987) won the Silver Lion at Venice -- to be followed (oddly enough) by only a year when The Legend of the Holy Drinker (1988) won the Golden Lion. During these absences, though seldom publicized, he had been wrestling with a long and sometimes paralysing illness.

At the 1994 Venice festival, on the occasion of the premiere of his Genesis: Creation and Flood, I had the good fortune to interview Olmi with other journalists, ${ }^{(1)}$ Olmi's masterpiece, The Tree of Wooden Clogs, was selected for the 1978 Cannes festival by Gilles Jacob, then the newly appointed délégué général, the decision was considered a risky one -- simply because this abridged version of the three-hour, three-part TV series about peasants and their will to survive in late 19th-century Lombard had to be projected in the Palais des Festivals in quadrangle-compressed TV format (at that time an exception to festival protocol).

Just as risky was the decision to present Cammina Cammina out-of-competition at the in 1983 Cannes festival. A rustic, folkloric, simplistic retelling of the story of the Magi, it came across to some as naive religious sentiment -- to Olmi defenders, however, as a poetic, colourful, vibrant hymn to the sheer beauty of Lombard pageantry. Much the same can be said about The Profession of Arms, the third film in Ermanno Olmi's historical "Lombard triptych," this one about the art of making war at a turning point in medieval history. Filmed on location in Bulgaria with Italian and Bulgarian actors, The Profession of Arms comes across again as an eye-filling panorama of dress, apparel, armour, weapons, banners, and all the courtly traditions of European statecraft -- indeed, as a tapestry of art and history as the Dark Ages faded into the flush of the Renaissance. Set in Lombard in 1520, this was the era of Erasmus and Machiavelli, of Leonardo da Vinci and Thomas More, of the Medicis in Florence and the Papacy in Rome, of new nations carved from feudal fiefs.

According to Ermanno Olmi, it was also a time when "a code of honour still characterized the noble art of warfare." Giovanni de Medici (Hristo Zivkov), a fringe member of the Medici family, was already a living legend at twenty. Known in the ranks of mercenary commanders as a great condottiere, his services were needed in a war waged between the Spanish and Papal armies. When he was brought down on the field by a cannonball, instead of dying bravely in hand-to-hand combat, his death marked a new era in which, says Olmi, "our wars of machines and technology make 'progress' ever more impersonal and deadly -- a 'progress' that has not guaranteed man's human, moral, and civil growth."

Afghan Enigma: Mohsen Makhmalbaf's Road to Kandahar

Query Mohsen Makhmalbaf as to why he would want to cross the border from Iran to Afghanistan to make Safar é Gandehar (The Road to Kandahar, aka Kandahar), and he'll cloak his answer in an treatise on why "The Buddha Was Not Demolished in Afghanistan -- It Collapsed Out of Shame," his documentation that accompanied the film's screening in Cannes. In other words, Mohsen Makhmalbaf wants to make sure the viewer doesn't miss the point when viewing his fiction-documentary about hunger, starvation, and death in today's Afghanistan. For Kandahar is hardly a film about Iran, although some 250 years ago Afghanistan did belong to the then Persian empire, nor is it set in the ancient Afghan city of Kandahar just across the border. Rather, it was researched and shot in Afghan refugee camps scattered along the Iran-Afghan border.

Mohsen's lengthy treatise is just as important as the film itself. Indeed, it makes obligatory reading to absorb the mountain of detailed information presented in The Road to Kandahar. Thus the fictional story serves as a frame to set the stage for the real-life drama, while at the same time evoking sympathy for the plight of Afghan refugees living abroad. Nafas (Niloufar Pazira), a young Afghan journalist who has taken refuge in Canada during the time of the civil war with the Taleban, receives a desperate letter from her younger sister in Afghanistan: she has decided to end her life on the day before the coming eclipse of the sun. Dropping everything to hurry back Kandahar to save her sister, Nafas tries to enter Afghanistan by the way she had previously exited the country -- via the Niatak refugee camp at the Iran-Afghan border. It's here that the film really begins.

In his wordy treatise Mohsen Makhmalbaf opens with the comments: "If you read this article in full, it will take about an hour of your time. In this one hour, some 14 more people will have died in Afghanistan of 
war and hunger, and 60 others will have become refugees of Afghanistan in other countries. This article is intended to describe the reasons for this mortality and emigration. If this bitter subject is irrelevant to your sweet life, please avoid reading it." Why the reference to the destroyed Buddha statue in the title of the treatise? "I reached the conclusion that the statue of Buddha was not demolished by anybody. It fell down out of shame -- out of shame for the world's ignorance towards Afghanistan. It broke down knowing its greatness didn't do any good."

More than likely, Makhmalbaf's decision to give flesh-and-blood to statistics by introducing the motif of desperation shared by the separated sisters stems from a personal experience. "Since the day I saw a little 12-year-old Afghan girl -- the same age as my own daughter Hanna -- fluttering in my arms of hunger, I've tried to bring forth the tragedy of this hunger. But I've always ended up giving statistics. Why have I become so powerless!"

When Makhmalbaf arrived in Kandahar with a small team, after months of wrangling with the Pakistan authorities (who represent Afghan's diplomatic interests abroad) to obtain the necessary visas, even the veteran filmmaker was taken back by the enormity of his task: "I never forget those nights during the filming. While our team searched the deserts with flashlights, we would see dying refugees left in the desert like herds of sheep. When we took those whom we thought were dying of cholera to hospitals in Zabol, we realized they were dying of hunger. Since those days and nights of seeing so many people starving to death, I haven't been able to forgive myself for eating any meals."

As for the imminent dangers of shooting in a country that doesn't tolerate images of any kind, Makhmalbaf could draw upon his own experiences of making another film on an Afghan theme: The Cyclist (1987), shot in Peshawar. "I remember the day I was arrested and handcuffed." And although friends and colleagues warned him to be careful on the Kandahar project, because of threats of kidnapping and terrorism at the borders, "I kept saying my subject was humanitarian and not political."

Even that turned out to be an illusion: "One day, when we were finished filming at the border, I come across a group that have come either to kill or kidnap me. They ask me about Makhmalbaf. I am sporting a long thin beard and wearing Afghan dress." A Massoudi hat with a shawl covering it and half of my face makes me look like an Afghan. I send them the other way and begin running. I cannot figure whether they have been dispatched by a political group or sent by smugglers to extort money."

The film finished, Mohsen Makhmalbaf has expressed his own doubts on "why did I make that film or write these notes? I don't know, but as Pascal put it: 'The heart has reasons that the mind is unaware of'." The Road to Kandahar was awarded the Ecumenical Prize at Cannes.

\section{Lenin's Last Days: Alexander Sokurov's Taurus}

The second in a planned trilogy on "men of power in the 20th century" -- the first was Moloch, his 1999 Cannes entry about Adolf Hitler that won the Best Screenplay award for collaborating poet Yury Arabov -Taurus focuses on the last days of Lenin, depicting the once powerful communist leader as a feeble, infirm, senile recluse living out his last days during the summer of 1923 in a confiscated country estate surrounded by his wife and sister, the guards and caretakers, the doctors and medical staff. Struck down by a second debilitating stroke that rubs out much of his memory, Lenin finds himself cut off from the rest of the world, particularly from the intrigues and manoeuvres of Trotsky and Stalin for top position in the Kremlin hierarchy.

For most of the film, Lenin (Leonid Mozgovoi) wrestles with his muddled thoughts and quarrels with his wife and sister as he tries to put together pieces of his past. Just as Eva Braun, bored and isolated, played a key role in Moloch, so too is some extra light thrown on Lenin's character by the presence of his wife Nadezhda Krupskaya (Maria Kuznetsova), and sister (Natalia Nikulenko). Midway though the film Joseph Stalin (Sergei Razhuk) arrives, and we sense that the reins of the Party are now firmly in his hands, save for the possibility that Lenin's last testament (requesting the removal of Stalin as General Secretary) might see the light of day. All four actors, to the director's credit, are dead ringers for the historical personages they interpret.

Alexander Sokurov described Lenin's last days so: "This family and this man have no home. Not only have they lost their home, but also the very possibility of ever having one. I would even say 'by definition' -- 
for whenever a man acquires a great deal of power, he loses his home. When there are no limits to power, there are no more limits to protect one's personal living space. Everything that you own by right of power invariably turns out to be not yours, but 'somebody else's' ... Even back then, this house had the appearance of the museum it would later be turned into."

A contrasting view by Yury Arabov, poet and screenwriter for all of Alexander Sokurov's feature films, on Lenin's last disabled year has a metaphysical ring: "The time for decisions was over. Having expunged God from his soul, he comes face to face with the only possible company. His only interlocutor, his confessor and his executor, is the approaching Non-Existence, Nothingness. This is, in fact, the main character of the film."

Of the three Russian stylists once named as "rightful heirs" to Andrei Tarkovsky -- Ivan Dykhovichny, the late Alexander Kaidanovsky, and Alexander Sokurov -- only Sokurov's cinema has survived the test of time. Always searching for new formulas to employ the language of cinema, he probes the human experience through the eyes of a skeptic and pessimist. One meeting with Alexander Sokurov is all that's needed to feel that down deep he's a restless man, a filmmaker who invites controversy by the very choice of his themes, an artist who will talk circles around the meaning of his films rather than offer any kind of direct answers that may come back later to haunt him.

Born in Siberia into a military family that was always on the move, he spent his childhood in Poland, his youth in Turkmenistan, and his university years in Gorky and Moscow before settling down in St. Petersburg to work at the Lenfilm Studios on documentaries and feature films. When his diploma film at the Moscow Film School (VGIK), The Lonely Voice of Man (1978), was rejected by school officials as being too negative and pessimistic, Andrei Tarkovsky was among those who spoke out in his defence. Moving on to Leningrad (today St. Petersburg) to make Lenfilm his permanent base, Alexander Sokurov spent most of the 1980s fighting to get his films released, if not completely banned with the negatives destroyed. In the case of The Summer of Maria Voynova, or Maria (1978/88), he had to wait a decade for this portrait of an exploited woman labourer on a collective farm to be released in its uncut version. His literary homage to George Bernard Shaw, Painful Indifference (1983/87), had to be pieced together from a partially destroyed negative when it was presented at the Berlinale.

Most critics have nothing but praise for his cycle of poetic "elegies" -- seven to date on key personalities in Russia and the ex-Soviet Union -- and his interview documentaries: Confession (1998), in which young Russian sailors openly speak their mind; The Knot (1998), a 90-minute interview with Alexander Solzhenitsyn; followed by Dialogues with Solzhenitsyn (1998). But it was his feature films that drew the most critical attention and prompted the comparison with Tarkovsky as a stylist with vision: Days of Eclipse (1988), Save and Protect (1989), The Second Circle (1990), and The Stone (1992).

Beginning with The Stone -- from a shelved screenplay titled Chekhov: The Last Year that dated from the late 1970s -- an optical "ashy haze" was introduced as a formal component, a stylistic trait reminiscent of the "gauzy mist" employed by Carl Theodor Dreyer to achieve the eerie atmosphere in Vampyr (1932). He perfected the camera technique in Mother and Son (1997), a poignant sketch of a son's undying love for his mother as he carries her to a resting place before she breathes her last breath, the soft images of the landscape are seen through the tears of the son. In Moloch (1999) it's the morning mists shrouding the castle-fortress in the Bavarian Alps that set the tone as Eva Braun restlessly awaits the arrival of Adolf Hitler and his guests. Now, in Taurus, photographed as well as directed by Sokurov, the last days of Lenin are filtered through opaque landscapes, grey skies, dimly lit interiors, and exaggerated sounds that vent the emotions of a troubled mind.

\section{Masters II: Shohei Imamura's Warm Water Under a Red Bridge}

Shohei Imamura's Akai hashi noshitano nurui mizu (Warm Water Under a Red Bridge) marks his fifth appearance in the official program at Cannes. Besides receiving the Palme d'Or for The Ballad of Narayama in 1983 and The Eel in 1997, he was here in 1987 with Zegen, The Lord of the Bordellos, based on the sexploits of Orient prostitution kingpin Iheiji Muraoka from 1902 to 1941; with Black Rain in 1989, an indictment of the atom bomb dropped on Hiroshima with its life-draining radiation effects lasting to the present day; and in 1997 with Kanzo sensei (Dr. Akagi) in 1997 , a touching homage to his own father as one of several dedicated country doctors who fought against hepatitis during the 1950s. 
A shy and modest man of recognized integrity in the ranks of veteran Japanese directors, the 74-year-old Shohei Imamura studied western history for five years at the University of Waseda, while at the same time taking an interest in theatre and writing his own plays for stage production. Several of the actors he worked with there -- Shoichi Ozawa, Kazuo Kitramura, Takeshi Kato -- later appeared in his films. Kazuo Kitramura, in fact, can be seen in Warm Water Under a Red Bridge in a supporting role.

In 1951, Imamura found work at Shochiku Studios as an assistant director to Yasujiro Ozu, Masaki Kobayashi, and Yoshitaro Nomura. Like Ozu, he prefers to let his films speak for themselves. Moving on to the Nikkatsu Studios in 1954, he collaborated with Yuzo Kawashima on his scripts and assisted So Yamamura and Kinuyo Tanaka on their productions -- until he could direct his first film in 1958: Stolen Desire. In 1965, he boldly created his own production company, thus becoming one of the pioneers of Japanese independent films. A perfectionist with a hand on every key element in a production, he has directed 19 films over the past 40 years. In addition, he founded in 1975 the Cinema and Television Institute of Yokohama, known today as the Japanese Academy of Visual Arts.

A director with a high regard for women and their place in Japanese society, Shohei Imamura feels that the 21st century will not only be the era of science and technology. "It will also be the era of women. The films I directed in the last century -- such as My Second Brother (1959), Pigs and Battleships (1961), The Insect Woman (1963), Intentions of Murder (1964), Eijanaika (1981), The Ballad of Narayama (1983), and Zegen (1987) -- all depict very strong women who accept their fates even in an era when women had been believed to have no actual practical role in society, or were simply regarded as 'inferior' to men."

In Warm Water Under a Red Bridge Yosuke (Koji Yakusho) has been laid off from work, his wife has left him but rings him regularly on his mobile phone to ask for money, and he wanders the streets of Tokyo in search of odd jobs. One day, he hears a story from an old homeless wanderer about a gold Buddhist statue stolen from a temple in Kyoto that's hidden in a vase lying underwater by a red bridge in a town on the Noto Peninsula of the Japan Sea. When the old man dies, Yosuke decides to go to the town and find the gold statue. Upon reaching his destination, he meets Saeko (Misa Shimizu), a kleptomaniac with the power to make flowers bloom out of season. Saeko, who lives with her grandmother in a house near a red bridge, suffers from not being able to hold water, a condition that's related to the mysterious water she secretes when experiencing physical pleasure..

Yosuke and Saeko are attracted to each other. When they first have sex, a gush of water springs forth from her body like a magic fountain, watering the flowers and attracting the fish. Thereafter it becomes a game: Yosuke has to be there when Saeko needs him -- until, gradually, he manages to cure her of her mysterious illness despite the forfeiture of his newly found pleasures. That's when another stranger from Tokyo suddenly appears in town. He, too, has heard the story from the old man about the vase in the water with the gold statue. No matter, for by this time the story has shifted to a lively comedy.

Imamura enthusiasts will appreciate the dramatic subtleties of the acting performances of Koji Yakusho and Misa Shimizu in Warm Water Under a Red Bridge. They are the same couple that appeared in The Eel. Yakusho was also seen last year at Cannes as the bus driver in Shinji Aoyama's Eureka and is currently recognized as Japan's leading male actor. The same goes for Misa Shimizu: after receiving the Japanese Academy Award for Best Actress for her role in The Eel, she now ranks among Japan's most sought-after actresses. When will we see the couple again on the screen? "Wait for the next Imamura film," quipped a Japanese critic.

\section{Family Dilemma: Shinji Aoyama's Desert Moon}

"In Eureka I observed the collapse of the modern family from the outside," said Shinji Aoyama in reference to the winner of the FIPRESCI Critics Prize and Ecumenical Award at last year's Cannes festival. "In Desert Moon I am looking at it from the inside. He added that the theme of the "family" transcends religion, ideology, or race in Japanese society. "I was hoping to catch a glimpse of this theme through the actions of the three main characters in Desert Moon."

In his earlier films, Aoyama told stories that focused on social misfits burdened with the psychological baggage of postwar Japan. Since the mid-1990s, when he burst upon the scene with the enigmatic It's Not in the Textbook (1995), a straight-to-video project, he has worked at a resolute pace reminiscent of 
the late Rainer Werner Fassbinder: Helpless (1995, awarded the Grand Prix at the Japanese Film Industry Professional Awards), Chimpira (Two Punks) (1996), Wild Life (1997), Tsumetai chi (An Obsession) (1997), Shady Grove (1999), Embalming (1999), Eureka (2000), the documentaries June 12, 1998 (2000) and Roji-e (2001), and now Desert Moon.

Born 1964 in Kita-Kyushu, Shinji Aoyama studied at Rikkyo University, where, influenced by Shingehiko Hasumi's classes on film criticism, he began to make $8 \mathrm{~mm}$ films: Straight to the Night and The Red Muffler. Upon graduating, he entered the film industry as a prop assistant, then rose to assistant director (Kiyoshi Kurosawa's The Guard from the Underground). Meanwhile, he contributed essays and criticism to Cahiers du Cinema Japan and Esquire Japan. Aoyama also worked as assistant director on Fridriksson's Cold Fever, the story of a Japanese youth journeying to Iceland to fulfill a burial ritual and thus pay due respect to his deceased parents, and assisted Swiss director Daniel Schmid on The Written Face, a made-in-Japan feature that incorporated native script and other traditional cultural images.

Shinji Aoyama is widely respected as a key figure in the current Japanese film revival. Take Riju Go's Chloe, for instance, the Japanese competition entry at this year's Berlinale. It's directed by the same actor who played the killer in the opening sequence of Aoyama's Eureka. Since Riju Go and Shinji Aoyama produce out of the same Tokyo-based Suncent Cinema Works, Aoyama return the Eureka compliment by acting in Go's Chloe -- he's the writer Kitano who gets killed along the way!

As for Eureka, a three-and-a-half-hour low-budget road-movie with improvised twists and turns in the casual story line, it drew its thematic strength from The Searchers (1956), a John Ford classic. In fact, the final scene in Eureka is almost a direct quote from the closing minutes of The Searchers, the scene in which John Wayne turns to Natalie Wood to say "let's go home" ... to start life all over again. The setting is Kyushu in southwest Japan, where on a hot summer morning a municipal bus is hijacked (by Riju Go) and only three people survive the carnage, among them the driver (Koji Yakusho, who played the lead in Shohei Imamura's The Eel, the 1997 Golden Palm co-winner).

Shot in black-and-white, sepia-tone cinemascope, Eureka took its title from a Jim O'Rourke rock album. According to the director, it's both an "inward road movie" and a "western movie tracing the journey of a soul" (thus the comparison with The Searchers, the John Ford classic), a multi-textured film that speaks to both the painful reality of contemporary Japan and the calamities suffered worldwide wherever the moral order is in evident disintegration. Its inspiration came from the recent sarin gas attack in the Tokyo subway and a rise in senseless violent crimes in Japan.

Shinji Aoyama is well aware of the dilemma of depicting the Japanese family in contemporary cinema: "Although impossible, I still hoped to describe in Desert Moon a family different from those depicted in the works of Yasujiro Ozu and Tatsumi Kumashiro. Because of the financial breakdown in Japan, culturally immature people from the middle class went through a kind of craziness. As a result, we are witnessing the total collapse of ethics. People are ready to sacrifice everything to maintain the same dreams they had in more affluent times. What I wanted to describe in this film is the needs of the contemporary family."

Nagai (Hiroshi Mikami), once regarded as a successful information-highway businessman, finds himself cornered. His company has gone public on the stock exchange, and he's now at the service of his stockholders. The goal he had longed to reach now seems "like a desert" stretching out before him, impossible to attain. Further, his wife Akira (Maho Toyota) and daughter Kaai have left him. To keep their memory alive, he carries their images around with him on a camcorder. He'd like to find them, but doesn't know where to begin. As for Akira, on the verge of sinking into alcohol, she's returned with Kaai to the countryside of her childhood. This is where the young mysterious stranger Keechie (Shuji Kashiwabara) enters the scene. Abandoned by his parents as a child and hardened by life on the streets, he will do anything for money, even kill if necessary. All three alienated figures converge at Akira's childhood refuge in the country.

Contrary to the tight narrative style that characterized Eureka, a wandering road-movie that unfolded gradually, Desert Moon makes its point at the outset and then portrays in detail the excruciating pains felt by all members of the divided family. One analogous scene introduced into the story underscores the dilemma of today's disintegrating Japanese family: Keechie is witness to a fit of rage as another homeless boy from the streets takes revenge on his drunken father by brutally killing him in a garage. 


\section{Taiwan Triumphs: Hou Hsiao-hsien and Tsai Ming-liang}

Altogether, 20 feature films from the Far East and the Subcontinent were programmed at Cannes: 8 in the Programme Officiel, 6 in Un Certain Regard, 4 in the Quinzaine des Réalisateurs, and 2 in the Semaine International de la Critic -- in addition to another 6 short films selected for these sections. The presence of three Japanese entries in the Competition was surely a first at Cannes, to say nothing of double entries from Taiwan. Critics noted the name Du Tuu-chih, who was awarded by the international jury the Technical Prize for Sound for his work on both films from Taiwan: Hou Hsiao-hsien's Qianxi mambo (Millennium Mambo) and Tsai Ming-liang's Ni nei pien chi tien? (What Time Is It There?).

The Palme d'Or for Best Short Film was awarded to David Greenspan's Bean Cake (Japan-USA). Yang Chao's Dai bi (Run Away) (China) shared the Third Prize in the Cinéfondation competition. Kiyoshi Kurosawa's Kä̈ro (Japan), an entry in Un Certain Regard, was awarded a FIPRESCI (International Critics) Prize. Iran continued its winning streak with two citations: Mohsen Makhmalbaf's Safar é Gandehar (The Road to Kandahar), a French coproduction, was awarded the Ecumenical Prize, while Sayyed Reza MirKarimi's Ziré nouré mâh (Under the Moonlight) received the Semaine Internationale de la Critique Award.

Time plays a central role in both Taiwanese films. In Hou Hsiao-hsien's Millennium Mambo we are asked to view the present from ten years hence -- in a flashback from 2011 -- with the focus on the drug-and-rave scene in today's Taipei, and it's anything but pretty. At the same time, Hou recalls his own youth: "Looking at young people around me, I find that their cycle and rhythm of birth, age, sickness, and death are moving faster than those of my generation. This is particularly true among young girls: like flowers, they start fading as soon as they bloom. The process occurs in an instant." In Tsai's What Time Is It There? a street-hawker sells a watch to a girl who's about to leave Taipei for Paris. Since it's a watch that shows two different time zones at once, the motif provides Tsai with the opportunity to narrate adjacent stories by cross-editing between what's happening in Paris and what's going on in Taipei. The twist comes when the boy is watching a pirated copy of Truffaut's Les quatre cent coups at the same time when the girl bumps into Jean-Pierre Léaud in the Père Lachaise cemetery.

\section{Yasunari Kawabata and Claire Denis: Trouble Every Day}

Part love story, part thriller, part vampire movie, Claire Denis's Trouble Every Day will not leave the viewer cold. Running out-of-competition, it was the most complex and consequent of all the films presented in the official program at Cannes. Denis describes the film as "a kind of dream, a dream I had as a child, not quite a nightmare. My mother tucks me in and devours me with kisses, because my skin has a milky aroma, she says, and because she can feel herself suddenly becoming an ogress once more (as if being an ogress was a natural, former state to have when in love). I clinch my eyes shut. I'm paralysed by her love and I wait for the bite ..."

Dreams, the world of literature, the moral questions of the day, all these are central to Claire Denis and crucial in plumbing the depth of her cinema. One glance at a British critics' poll taken last year is all you need to know about the international status of the French woman director: her Beau Travail (Good Work) was cited by nearly all among the Ten Best Films released in 2000. Presented in the competition at the 1999 Venice festival, Beau Travail drew upon Herman Melville's Billy Budd, a refined literary work found among the American writer's papers in 1924, to fulfill an assignment at La Sept-ARTE on the theme "Foreign Countries" -- namely, stories about French people living abroad.

Since Denis had been raised in Africa, she returned to the Gulf of Djibouti, where the French Foreign Legion maintains a training base, to explore the moral question of good and evil, love and hate, in a closed community as recorded in the diary of Galoup (Denis Levant), a jealous non-commissioned officer and exlegionnaire. Three years in the making, and filmed almost without dialogue, Good Work fascinates as a chain of episodes minimalist in concept and impressionistic in realization. Further, this choreography of naked, muscular, gleaming, sun-baked male bodies -- moving in rhythm against a backdrop of sea, sand, and desert -- were enhanced by camerawoman Agnès Godard's remarkable talent for detail and composition.

Added to this "ballet in the desert" were subtly integrated chords from Benjamin Britten's opera Billy Budd. Even more significant were the giveaway references to key French films of the past about the African Question and the Algerian War -- namely, the presence of Michel Subor in Beau Travail as the helpless commanding officer. Subor had previously played nearly the same role in Jean-Luc Godard's Le Petit Soldat 
(1960), an outspoken anti-Algerian War film. Not to be forgotten either is Claire Denis's own Chocolat (1988), her debut feature film invited to compete at Cannes. Like Beau travail, it drew upon experiences of her own childhood in Africa, particularly growing up in the home of a French diplomat stationed in the Gulf of Djibouti. Chocolat, with its metaphorical reference to a black culture, came across to this viewer as a haunting dream.

Now the circle has closed, and Claire Denis is back in Cannes with a film inspired by a novel by Yasunari Kawabata, awarded in 1968 the Nobel Prize for literature. Denis cites Kawabata as a writer who has always been an important cinematic source for her. The author of over 500 novels and short stories, Kawabata took his life in 1972 at the age of 72 , his death usually credited to having taken addictive sleeping medicine for the last fifty years of his life that eventually took its toll upon his brain. This said, the sure cinematic reference to Trouble Every Day, a weird tale of brain research and "the bite of the vampire," is found in Kawabata's own life and one of his heralded masterpieces: The House of Sleeping Beauties, published in 1960.

The key literary passage that fascinated the filmmaker begins with an ominous moral discovery: "One day, when Eguchi withdrew his face from her, he noticed pearl drops of blood around her nipple. Eguchi had been surprised. He had concealed his emotions, however, and bringing his mouth slowly to her breast he had drunk her blood. In her ecstasy the girl had not noticed... The feeling that he had secured from her a gift capable of increasing man's strength had not faded even now, at the venerable age of $67 . "$

"I wanted to make a film about love," said Claire Denis about Trouble Every Day: "There won't be violence at first, but desire: bodies giving themselves up, lips reaching out, opening. The man says to his woman (or vice-versa): my love, I am going to devour you with love." The American newly-weds, Shane (Vincent Gallo) and June (Tricia Vessey), are in Paris on their honeymoon. But it's not an ordinary honeymoon. In the past Shane has been involved in experiments into the human libido and is tormented by a ravenous hunger that will not be quieted. He is in Paris to find Léo (Alex Descas), who has been expelled from the same laboratory Shane once worked at. Léo now spends his time at home with Coré (Béatrice Dalle), his ill wife, while still continuing to work on experiments forbidden by the government for secret reasons.

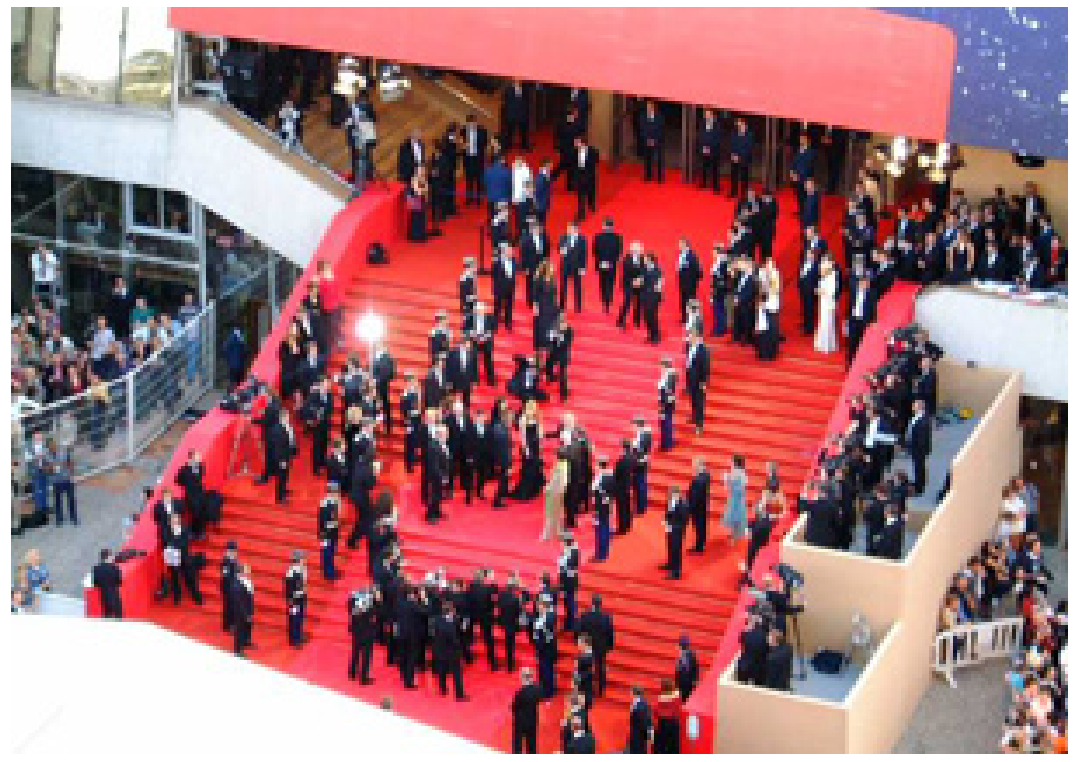

Figure 2: The Red carpet

\section{Masters III: Manoel de Oliveira, Jacques Rivette, Jean-Luc Godard}

Three seemingly ageless veteran directors -- Mañoel de Oliveira (93), Jacques Rivette (73), and Jean-Luc Godard (70) -- competed with entries that received warm reviews, but they were also crowd-pleasers and will surely make the rounds of major festivals on the circuit in the months to come. By an odd coincidence, all deal with theatrical performances or related artistic expression, and each is anchored to the imperative of love. 
In Oliveira's Vou para casa (I'm Going Home, Portugal-France) Michel Piccoli is a stage actor who has played all the major roles in a long and fruitful career. One evening, after performing Ionesco's Exit the King, he receives word from an old friend that his wife, daughter, and son-in-law were killed in an auto accident. The wounds mend slowly, mostly because there's his grandson to look after and dote on. Then comes the role of Prospero in Shakespeare's The Tempest, along with an acquaintance with a young actress playing Miranda, and life gets a lift. Appearances by Catherine Deneuve, John Malkovich, and Sylvie Testud make I'm Going Home a delight.

In Jacques Rivette's Va Savoir (Who Knows, France) an Italian troupe from Turin arrives in Paris to perform Pirandello's As You Desire Me, the title alone setting the stage for the real-life drama. The play's lead actress Camille (Jeanne Balibar) had left Paris three years before because of Pierre (Jacques Bonnaffe), whom she doesn't want to meet again because of her new relationship with stage director Ugo (Sergio Castellitto). Ugo, too, has a secret: the visit to Paris allows him to search for a lost Goldoni manuscript, but leads him instead to the seductive Dominique (Hélène de Fougerolles). Each of the protagonists is confronted with a certain truth about themselves as the plot meanders along in different directions. Indeed, since the director pulls ideas out his pocket on the very day of shooting, Who Knows offers riddles that only the audience can really resolve -- a winsome comedy and vintage Rivette.

In Jean-Luc Godard's Eloge de l'amour (Eulogy of Love, France) the setting is again Paris and marks a return of the director from experimental video to conventional filmmaking. "I had a vague idea that had a title," announced Godard in his usual cryptic manner. "I had something usually known as a love story. My idea was to relate it counter-chronologically." In other words, the end is at the beginning and the beginning at the end. Further, the story is told through three couples of different ages: young, adult, and old. All are asked in the film to work on a "project" -- something between an opera and a movie, a play or a novel. The link that ties the stories together is four key moments of love -- meeting, passion, separation, reunion -- akin to the four seasons, in nature and in life. Each episode was shot separately, then integrated into a whole -- backwards -- during the editing process. Is Eulogy of Love a drama? An essay? A mellowed Godard reflecting on his own past? Probably all of these, but maybe something more -- a eulogy of love in the sense of praise of the everlasting and esteem for the eternal.

\section{Courts Métrages \& Cinéfondation}

"A basket of jewels" best describes the 12 short films competing for Palme d'Or honours. Judged by a separate international jury headed by French director Êrick Zonca, it's also awarded prizes to entries in the Cinéfondation competition. Each short in the Official Program had its own style, some with a surprise twist, others with a profound human message. For example: David Greenspan's Bean Cake (Japan-USA), awarded the Golden Palm. The story of a poor lad whose mother cannot afford to pay for a proper uniform on the first day of school, he is made fun of by his classmates but still has the pride to stand up for his favourite snack. Or Irvine Allan's Daddy's Girl (UK), in which a cowed and freezing 7-year-old girl stands in the rain before a pub waiting for her father, who's inside drinking. A touching film that goes right to the bone, it was awarded the Special Jury Prize.

Last year, the Cinéfondation consisted of two full programs. This year, four programs with 20 films contended for top honours. The First Prize was awarded to Sergei Luchishin's Portrait (Russia-Ukraine), a short feature of 18 minutes directed by a Ukrainian student at the Moscow Film School (VGIK). As witty as it is critical, this bittersweet portrait of Moscow is seen through the eyes and experiences of an artist lost in a city of moral decay. It should be noted that the Cinéfondation is already recognized as an effectual stepping stone to Un Certain Regard. Award-winners can easily gain entrance to the Résidence Cinéfondation in Paris for a fourmonth stay to develop a feature film project. Two directors previously awarded in the 1999 Cinéfondation competition were invited to Un Certain Regard this year. Dover Kosashvili's With Rules (Israel-Georgia) paved the way for Late Marriage, just as Jessica Hausner's Inter-View (Austria) opened the door for Lovely Rita (Austria Germany).

After the daily ordeal of watching a string of feature films, some rather long and demanding to sit through, the respite offered by the short films was a welcomed treat. Besides the 32 shorts seen in the Official Program, another 12 were programmed in the Quinzaine des Réalisateurs -- plus three experimental entries under the rubric En Avant! -- and the International Semaine de la Critique programmed 7 short features before each 
of the selected features, in addition to a "fête le court" that ran all day long and through the night.

Celebrating its 40th anniversary, the International Week of the Critics under programming director José María Riba paid a fitting tribute to German director Percy Adlon. Some Cannes veterans remembered how, back in 1981, Percy Adlon presented his debut feature Céleste to an overflow the French crowd of Marcel Proust fans in the Cinéma Le Français on the rue d'Antibes, the venue of the German series in the Cannes film market. Based on an autobiography by Proust's housemaid, it recounted the living and working habits of the French author while writing $\grave{A}$ la cherche du temps perdu, starred Eva Mattes in the title role of the housemaid, and helped considerably to launch the director internationally.

Now, twenty years on, Percy Adlon was back in Cannes with a trio of quaint shorts from his Die Strausskiste (Forever Flirt) series, all based on musical motifs -- waltzes and marches -- in the works of Johann Strauss Jr. In Nijinsky at the Laundromat a homeless dancer undresses completely at a laundromat and waits for his clothes to dry while reading Nijinsky's diary. In The Autograph the setting is St. Petersburg, where a student and famous conductor are having an affair. In Triumph of the Kiss a love parade and kissing celebration pair with a Strauss march that quotes from the same Haydn melody found in the German national anthem. That Percy Adlon has a deft hand for such cinematic études has been evident ever since Die Schaukel (The Swing, 1984), his warm, poignant family tale set in the gardens and palaces of München at the turn-of-the-century.

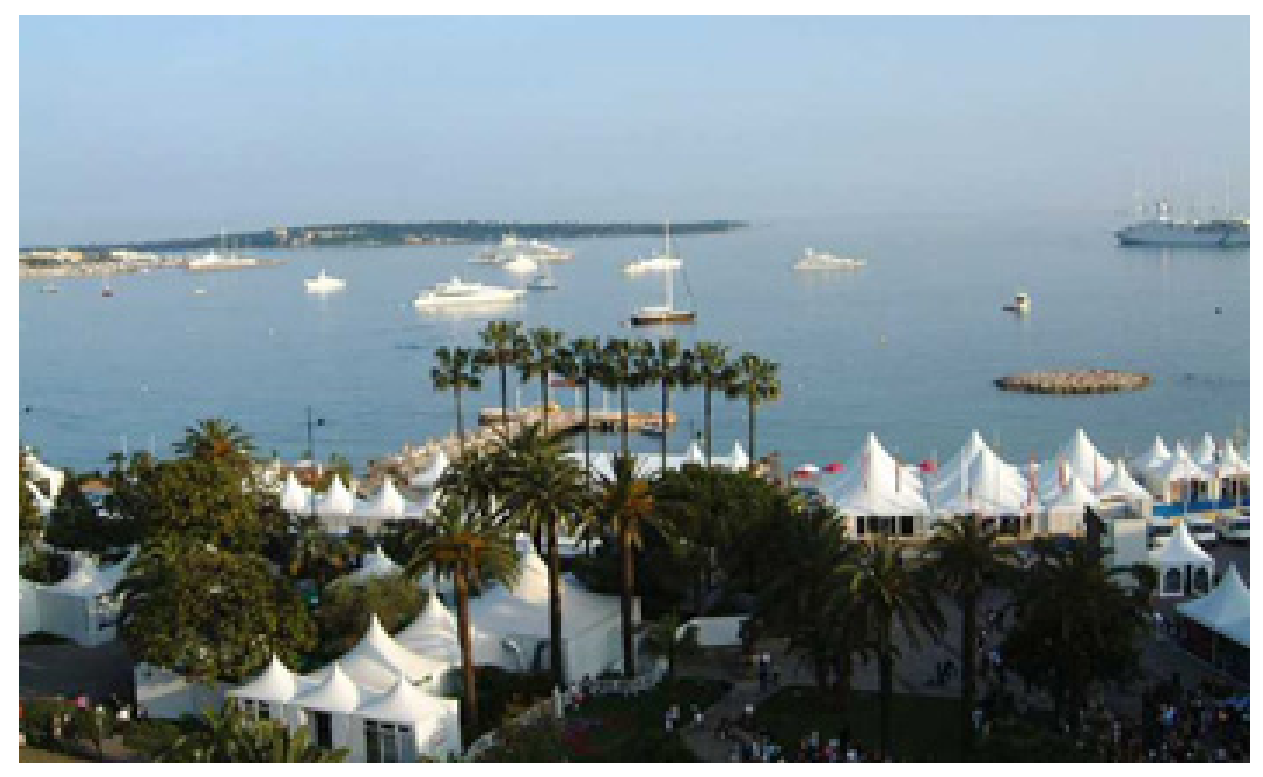

Figure 3: The Bay of Cannes

\section{Notes}

1. See "Venice 1994: Ron Holloway on Ermanno Olmi's Genesis, Kinema No.3, Spring 1995.

\section{References}

\section{AWARDS}

\section{Official Competition}

Golden Palm: La stanza del figlio (The Son's Room, Italy), director Nanni Moretti

Grand Jury Prize: La pianiste (The Piano Teacher, Austria/France), director Michael Haneke 
Best Actress: Isabelle Huppert in La pianiste (The Piano Teacher, Austria-France), director Michael Haneke

Best Actor: Benoît Magimel in La pianiste (The Piano Teacher, Austria-France), director Michael Haneke

Best Director (ex aequo): Joel Coen, The Man Who Wasn't There (USA), and David Lynch, Mulholland Drive (USA)

Best Screenplay: Danis Tanovic, No Man's Land (France-Belgium-Italy-UK-Slovenia), director Danis Tanovic

Technical Prize for Sound: Du Tuu-chih for both Qianxi mambo (Millennium Mambo, Taiwan-France), director Hou Hsiao Hsien and Ni nei pien chi tien (What Time Is It There? (Taiwan-France), director Tsai Ming-liang

Short Film Awards

Golden Palm: Bean Cake (USA-Japan), director David Greenspan

Special Jury Prize: Daddy's Girl (UK), Irvine Allan

Jury Prize: Pizza Passionata (Finland), Kari Juusonen

Cinéfondation Awards

First Prize: Portrait (Russia), director Sergei Luchizhin

Second Prize: Reparation (Sweden), director Jens Jonsson

Third Prize (ex aequo): Dai bi (Run Away) (China), director Yang Chao, and Crow Stone (UK), director Alicia Duffy

Camera d'Or (Best Debut Feature): Atanarjuat the Fast Runner (Canada), director Zacharias Kunuk

International Critics (FIPRESCI) Awards:

Competition: La stanza del figlio (The Son's Room, Italy), director Nanni Moretti

Un Certain Regard: Kä̈ro (Japan), director Kiyoshi Kurosawa

Quinzaine des Réalisateurs: Martha... Martha (France), director Sandrine Veysset

Semaine Internationale de la Critique: Le pornographe (The Pornographer, France), director Bertrand Bonello

Ecumenical Award: Safar é Gandehar (The Road to Kandahar, Iran-France), director Mohsen Makhmalbaf Semaine Internationale de la Critique Award: Ziré nouré mâh (Under the Moonlight, Iran), Sayyed Reza Mir-Karimi

\section{Author Information}

Ron HOLLOWAY (1933-2009) was an American critic, film historian, filmmaker and correspondent who adopted Europe as his home in the early fifties and spent much of his life in Berlin. He was an expert on the 
study of German cinema and against all odds produced, with his wife Dorothea, the journal German Film, keeping us up-to-date with the work of directors, producers and writers and the showing of German films around the world.

In 2007, Ron Holloway and his wife were awarded the Berlinale Camera Award. Ron also received the Bundesverdienstkreuz (German Cross of Merit), Polish Rings, Cannes Gold Medaille, the American Cinema Foundation Award, the Diploma for Support of Russian Cinema and an honorary award from the German Film Critics' Association.

Ron was also a valued contributor to Kinema for the past fifteen years. 